\title{
Special issue: ACMT - conference on Advanced and Competitive Manufacturing Technologies in Moscow
}

๑) Springer-Verlag London Ltd., part of Springer Nature 2021

The following articles are part of the Special Issue "ACMT - conference on Advanced and Competitive Manufacturing Technologies in Moscow" Guest Edited by Andrey Kutin and Konrad Wegener and were inadvertently published in a different issue:

Kirchheim, A., Katrodiya, Y., Zumofen, L. et al. Dynamic conformal cooling improves injection molding. Int $J A d v$ Manuf Technol 114, 107-116 (2021). https://doi.org/10. 1007/s00170-021-06794-0

Leonesio, M., Wojcicki, J. \& Bianchi, G. Geometrical optimization of centerless grinding process by profiled workrest. Int J Adv Manuf Technol 114, 3069-3075 (2021). https://doi. org/10.1007/s00170-021-07040-3

Publisher's Note Springer Nature remains neutral with regard to jurisdictional claims in published maps and institutional affiliations. 